\title{
Energy Planning Implementation in Hotels. Case Study in a Hotel in the City of Barranquilla-Colombia
}

\author{
Andres Rodriguez Toscano ${ }^{1}$, Juan J. Cabello Eras ${ }^{1, *}$, Fabrizio Galeano Viviente $^{2}$, Alexis Sagastume \\ Gutierrez $^{1}$ and Yabiel Pérez Gomez ${ }^{3}$
}

\author{
${ }^{1}$ Universidad de la Costa, Street 58 \# 55e66, Barranquilla, Atlántico, Colombia, \\ ${ }^{2}$ Energía Óptima SAS, Carrera 50 No 61200, Barranquilla, Atlántico, Colombia \\ ${ }^{3}$ University of Cienfuegos, Road to Rodas, $\mathrm{km} \mathrm{4}$, Cuatro Caminos, Cienfuegos, Cuba,
}

Received 12 December 2018; Accepted 24 September 2019

\begin{abstract}
This article presents the results of energy planning in a hotel in the city of Barranquilla, Colombia, according to ISO 500001 standard methodology. The energy performance of the hotel was assessed, a low capacity for energy management was found and the main electricity consumers were identified and several energy-saving measures associated to bedrooms management and air conditioner operation were proposed and implemented reaching a 19,3\% of energy-saving. Also, a methodology to energy planning in hotels also was proposed and validated
\end{abstract}

Keywords: Energy planning, energy efficiency, energy indicators, energy consumption in hotels.

\section{Introduction}

The tourism sector is among the most dynamically growing internationally [1]. The World Tourism Organization estimates an annual growth of 3.3\% for the period 2010-2030 and a contribution of $5 \%$ of the total global carbon dioxide emissions for the same period $[2,3]$.

In several countries, buildings for hotels are among the largest consumers of energy [4]. Energy consumption in hotels is generally one of the highest operating costs $[5,6,7]$, only exceeded by personnel costs $[8,9,10,17]$. Therefore, the efficient use of energy is a key opportunity to reduce costs and improve the competitiveness of hotels, contributing to the environment and improving their business image [8, 9, 10].

A study carried out in hotels in southern Europe revealed a potential for savings of $25 \%$ to $30 \%$, especially in hotels with high electricity consumption $[11,12]$. Potential savings were also estimated between $15 \%$ and $20 \%$ for heating, between $5 \%$ and $30 \%$ for air conditioning and refrigeration, and between $7 \%$ and $60 \%$ for lighting [11]. The buildings destined to be hotels have their own characteristics since their main objective is to guarantee the comfort of guests in all their services and at all times $[1,13]$, which influences the uses of energy [11] and has high potential savings $[11,9,14]$.

Energy management has made significant progress in many countries $[15,16,17,18,5,19,9,8]$. However, it is not common to find energy planning programs, sustainability, and research reports in the specialized literature of hotels in Latin America in the Caribbean region, particularly in Colombia.

The tertiary sector in Colombia represents around $6 \%$ of total energy consumption and is the most dynamic. Its growth

\footnotetext{
*E-mail address: jcabello2@cuc.edu.co

ISSN: $1791-2377$ @ 2019 School of Science, HHU. All rights reserved.

doi:10.25103/jestr.125.10
}

rates in recent years are between $7 \%$ and $12 \%$ annually, the hotel subsector being the third line of exports and the first in the tertiary sector, with a growth forecast of 5\% per year until 2030 [20]. In Colombia, tourism priorities are established through the tourism sector plan 2014-2018 [21, 22]. However, it does not directly address the issue of energy efficiency (EE) as one of the possible actions to improve competitiveness in hotels $[10,13]$ and only gives general recommendations for energy savings [22].

The paper is focused to propose a methodology to energy planning in conditions of hotels in Colombian tropical conditions, the methodology is applied and validated in a hotel in Barranquilla with a significant energy saving results throughout energy-saving measures identified and applied which could be useful for other hotels in the region..

\section{Methodology}

In 2011, with the approval of the ISO 50001 standard, an international standard was arranged that establishes the general requirements of an Energy Management System. The ISO 50001 standard proposes four basic stages that are: (1) Energy policy, (2) Energy planning, (3) Implementation and (4) Verification. All the stages are inserted in a cycle of continuous improvement $[23,5,24]$. This study was carried out in a hotel in the city of Barranquilla-Colombia, following the steps of energy planning stipulated in the ISO 50001 standard (see figure 1), and as a methodology, the energy indicators ISO 50004 and ISO 50006 [23, 5]. In figure 1, the energy planning diagram is shown.

Energy planning consists of three components that are: Entries, energy review and outputs (see figure 1). The entries consist of an analysis of historical and current energy consumption, and the identification of the variables that affect it. The energy review is carried out from the analysis of the 
production or activity with the energy consumption, the significant areas of energy consumption and savings opportunities are identified. Finally, the outputs of the process are: the baseline, the energy indicators, the objectives, the goals and the action plan [25]. Figure 1, next to each component of the energy planning, shows the number of the section where it is developed. In this study, the tools proposed in the ISO 50001 standard and the specialized literature were used: The energy management evaluation matrix (see table 1 and figure 2) [26], analysis of energy consumption with production (see figure 3) [27, 9, 28, 29], scatter and correlation diagrams for the baseline and target line (see figure 4) $[28,23,30]$, Pareto diagrams for the load and identification census of the most significant consumptions and of the areas of interest (see figure 5 and 6) [28, 23]., base energy indicator 100 (see figure 8) (ISO, 2011) and CUSUM control charts (see figure 9) [28, 23].

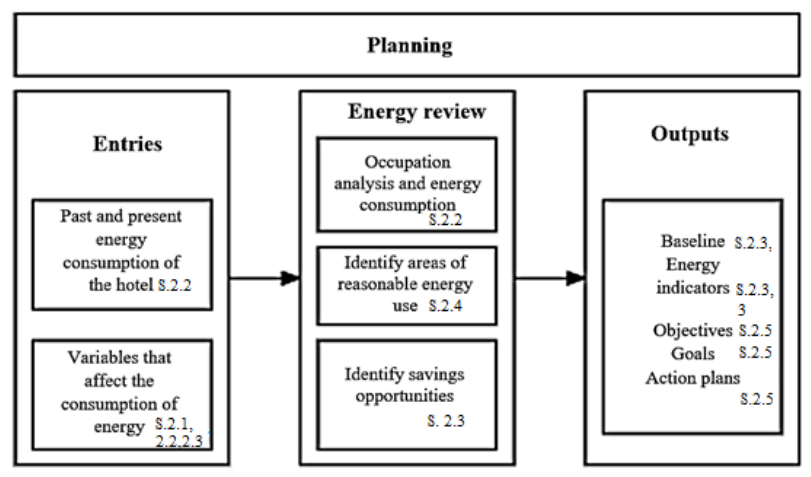

Fig. 1. Components of energy planning in a hotel [23]

In relation to the technical procedures to carry out the energy measurements and technical studies on the equipment and facilities of the hotel, the technical regulation of electrical installations RETIE was used [21]. The measuring instruments were: A PQA824 electrical network analyzer which complies with the measurement and recording of the network parameters according to EN50160 Standard, a digital voltmeter MT4W-DV-41 with input ranges of $50,250 \mathrm{mV} / 1$ , 5, 10, 50, $100500 \mathrm{~V} \mathrm{DC}$, a digital thermohigrometer LM$81 \mathrm{HT}$ for ranges of relative humidity of $10-95 \% \mathrm{RH}$ and with a thermal camera FLIR E4 [31] with a precision of $2 \%$.

\section{Case study}

The object of study is a hotel located in the city of Barranquilla-Colombia with an ambient temperature between 23.2 to $33{ }^{\circ} \mathrm{C}$ and relative humidity between $77 \%$ and $90 \%$. The hotel has 91 rooms, a Lobby Bar with internal and external exit, a swimming pool, a kitchen, a laundry, a warehouse, an executive lounge with capacity for 100 people, and a parking lot. The technological equipment includes nine condensers, 91 mini split units with temperature and flow controllers located in each room, four freezers, four refrigerators, two washing machines, a dryer, two motor pumps, a LED lighting system and an electric motor running 24 hours a day, 365 days a year. The study time established in this investigation involves the months from April 2015 to February 2017.

\subsection{Diagnosis of the energy level management}

In order to know the current status on the general aspects such as energy policy, organization, motivation, information system, marketing and investment relating to energy management in the hotel, a diagnosis was made through a matrix of competence on the hotel's energy management [10, $26]$. For this, interviews were carried out with the personnel in charge of the maintenance and the management of the hotel, which allowed each of the evaluated aspects to be rated.

Table 1. Energy Management Matrix [26, 32, 33].

\begin{tabular}{|c|c|c|c|c|c|}
\hline Level & Organization & Staff motivation & $\begin{array}{c}\text { Tracking, } \\
\text { monitoring and } \\
\text { reporting systems }\end{array}$ & $\begin{array}{c}\text { Staff awareness/ } \\
\text { training and } \\
\text { promotion }\end{array}$ & Investment \\
\hline 4 & $\begin{array}{l}\text { Energy management } \\
\text { policy, action plan and } \\
\text { regular review have } \\
\text { commitment of top } \\
\text { management as part of } \\
\text { a corporate strategy. }\end{array}$ & $\begin{array}{l}\text { Formal and informal } \\
\text { channels of } \\
\text { communication } \\
\text { regularly exploited by } \\
\text { energy manager and } \\
\text { energy staff at all } \\
\text { levels }\end{array}$ & $\begin{array}{c}\text { Comprehensive } \\
\text { system sets targets, } \\
\text { monitors } \\
\text { consumption, } \\
\text { identifies faults, } \\
\text { quantifies savings } \\
\text { and provides } \\
\text { budget tracking }\end{array}$ & $\begin{array}{l}\text { Marketing the } \\
\text { value of energy } \\
\text { efficiency and the } \\
\text { performance of } \\
\text { energy } \\
\text { management }\end{array}$ & $\begin{array}{c}\text { Positive } \\
\text { discrimination in } \\
\text { favour of energy } \\
\text { saving schemes } \\
\text { with detailed } \\
\text { investment } \\
\text { appraisal }\end{array}$ \\
\hline 3 & $\begin{array}{c}\text { Formal energy } \\
\text { management policy, } \\
\text { but no active } \\
\text { commitment from top } \\
\text { management }\end{array}$ & $\begin{array}{l}\text { Energy committee } \\
\text { used as main channel } \\
\text { together with direct } \\
\text { contact with major } \\
\text { users }\end{array}$ & $\begin{array}{l}\text { Monitoring and } \\
\text { targeting reports } \\
\text { for individual } \\
\text { premises }\end{array}$ & $\begin{array}{c}\text { Program of staff } \\
\text { training, awareness } \\
\text { and regular } \\
\text { publicity } \\
\text { campaigns. }\end{array}$ & $\begin{array}{l}\text { Cursory appraisal } \\
\text { of new building, } \\
\text { equipment and } \\
\text { refurbishment } \\
\text { opportunities }\end{array}$ \\
\hline 2 & $\begin{array}{c}\text { Unadopted energy } \\
\text { management policy set } \\
\text { by energy manager }\end{array}$ & $\begin{array}{l}\text { Contact with major } \\
\text { users through adhoc } \\
\text { committee }\end{array}$ & $\begin{array}{l}\text { Monitoring and } \\
\text { targeting reports } \\
\text { based on supply } \\
\text { meter data }\end{array}$ & $\begin{array}{l}\text { Energy unit has } \\
\text { adhoc involvement } \\
\text { in budget setting. }\end{array}$ & $\begin{array}{l}\text { Investment using } \\
\text { shortterm } \\
\text { payback criteria } \\
\text { only }\end{array}$ \\
\hline 1 & $\begin{array}{l}\text { An unwritten set of } \\
\text { guidelines. Energy } \\
\text { management the part- } \\
\text { time responsibility }\end{array}$ & $\begin{array}{l}\text { Cost reporting based } \\
\text { on invoice data }\end{array}$ & $\begin{array}{l}\text { Energy manager } \\
\text { compiles reports } \\
\text { for internal }\end{array}$ & $\begin{array}{l}\text { Informal contacts } \\
\text { used to promote } \\
\text { energy efficiency }\end{array}$ & $\begin{array}{l}\text { Only low-cost } \\
\text { measures taken }\end{array}$ \\
\hline 0 & $\begin{array}{l}\text { No explicit policy. No } \\
\text { energy manager }\end{array}$ & No information system & $\begin{array}{l}\text { No accounting for } \\
\text { energy } \\
\text { consumption }\end{array}$ & $\begin{array}{l}\text { No promotion of } \\
\text { energy efficiency }\end{array}$ & $\begin{array}{c}\text { No investment in } \\
\text { increasing energy } \\
\text { efficiency }\end{array}$ \\
\hline
\end{tabular}




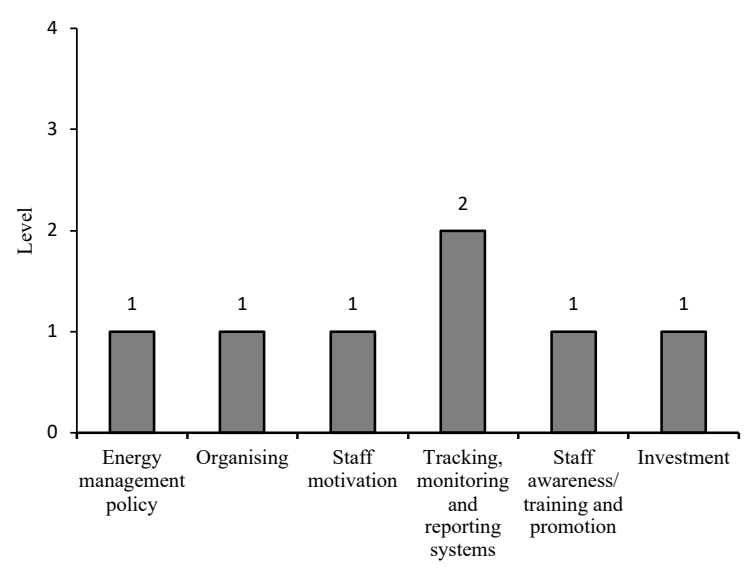

Fig, 2. Result of the self-assessment of the Energy Management Matrix.

The result shown in the figure shows a low level of management. Only the Tracking, monitoring and reporting systems reach level 2, the rest of the systems are in level 1 (below average) on a scale of 0 to 4

Therefore, in the hotel there is an incipient level of energy management with few human resources professionally trained in energy management, there are no records of energy indicators, sound energy policies, or effective control of energy resources since its inauguration and commissioning in 2015.

\subsection{Analysis of energy consumption and occupancy in the hotel}

Figure 3 shows the correspondence between the monthly behavior of energy consumption and the day occupancy rooms (HDO) between April 2015 and March 2016, so the relationship between both variables can serve as an indicator of energy efficiency [5]. In addition, the probability that, when the hypothesis that HDO do not influence the variability of electricity consumption is true, is not true because the pvalue is less than 0.05 .

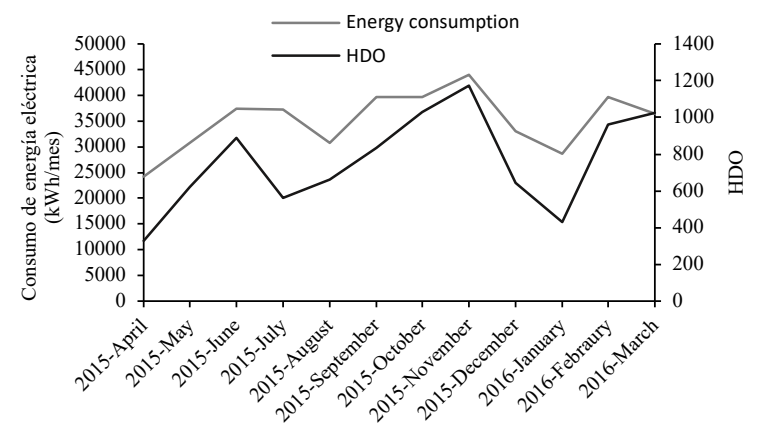

Fig. 3. Behavior of energy consumption and occupation level.

Figure 3 shows that when the HDO is increased, its activity increases and, therefore, it needs a greater number of equipment operating, to maintain the comfort of its guests. In April, there are no festivities, strategies, or tourist attractions that stimulate the massive arrival of guests, however, HDO and electricity use increases as June approaches the arrival of guests who wish to spend family vacations in Barranquilla . In July, there is a slight decrease in electricity consumption due to a decrease in HDO, nevertheless its behavior is due to the hotel develops strategies in HDO prices to try to attract more guests and maintain what it has. Between September and November, electricity consumption increases and the HDOs reach the highest values, however, having a high number of HDO implies an increase in the frequency of use of a room and, therefore, of spending less energy due to the non-administration or proper allocation of the rooms according to the use of electricity. Between December and January, the HDO and the consumption of electricity decreases due to the end of the year festivities, but between February and March the consumption of electricity and the HDO increases due to the cultural festivities. On the other hand, figure 3 shows in the month of March there was an atypical behavior in consumption since most of the guests stayed the longest outside the hotel and only came to rest in the early morning due to the Carnival.

In similar environmental conditions, there are several researches in which it is suggested that the ambient temperature under certain conditions does not have a significant impact on the variability of electric power consumption [5]. In the hotel under study (Barranquilla, Colombia), the ambient temperature influences the energy consumption because it is between $22.3^{\circ} \mathrm{C}$ and $33^{\circ} \mathrm{C}$, however, it has little variability on the energy consumption in the period of study because it is seasonal and varies little throughout the year [34]. Therefore, its participation on energy indicators is ruled out.

2.3 Selection of energy efficiency indicators and establishment of the base line, target line and potential savings.

The Energy Performance Indicators (IDEn) have the purpose of evaluating energy efficiency and monitoring it $[23,25]$. In the specific case of hotels, several studies recommend the use of indicators by the relationship of energy consumption and the level of occupation generally evaluated as $\operatorname{HDO}[35,16$, $5,35,36,37,17,38]$. Other authors propose the use of indicators obtained from the relation energy consumption and the built area of the hotel $\left(\mathrm{kWh} / \mathrm{m}^{2}\right)$ mainly, for comparative studies of energy efficiency between different tourist facilities $[1,35,37]$.

Figure 4 shows the baseline and the target line of the hotel's electricity consumption, the coefficient of determination reached is $\mathrm{R} 2=0.78$ greater than 0.6 , the limit indicated in the literature to consider that the model is effective $[27,9,28,29]$. The baseline, serves as a reference for the behavior of energy consumption and occupation in 2016. With this, energy not associated with occupation is identified with a value of $20,476 \mathrm{kWh}$. The slope of the baseline represents the energy associated with the occupation.

Figure 4 shows that the intercept with the vertical axis of the two lines (baseline and target line) represents the energy consumption of the hotel without guests. In Figure 4, the target line shows a good expectation of energy efficiency as a savings opportunity considering that $58.3 \%$ of consumption data are below the baseline. That $58.9 \%$ of the data are below the baseline indicate that the hotel has had more than $50 \%$ of the total operating states, efficient. These operating states or conditions can be replicated to save electricity.

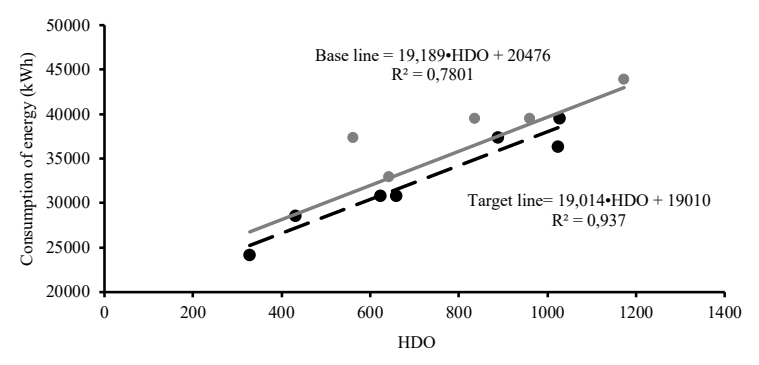

Fig. 4. Energy baseline and HDO. 


\subsection{Energy diagnosis and identification of areas with} significant use of energy

In the energy review, the current state of the equipment and the bad operational practices are evaluated in order to identify the areas with the highest energy consumption and to potentiate the processes. The physical areas of the hotel that involve the relevant processes (food, lodging, administration and recreation) were subdivided (parking, laundry, kitchen, storage, rooms, lobby, administrative area and bar). For the energy diagnosis the following steps were followed: 1 . Analysis of the diagram or electrical plans of the hotel; 2 . Measurement of energy consumption in the different areas of installation; 3. Identify the areas with reasonable use of electricity; 4. Identification of bad operational practices; 5 . Hotel loading census; 6. Identify the main electricity consuming equipment or systems and 7 . Savings proposal. Figure 5 shows the areas of greatest electricity consumption of the hotel.

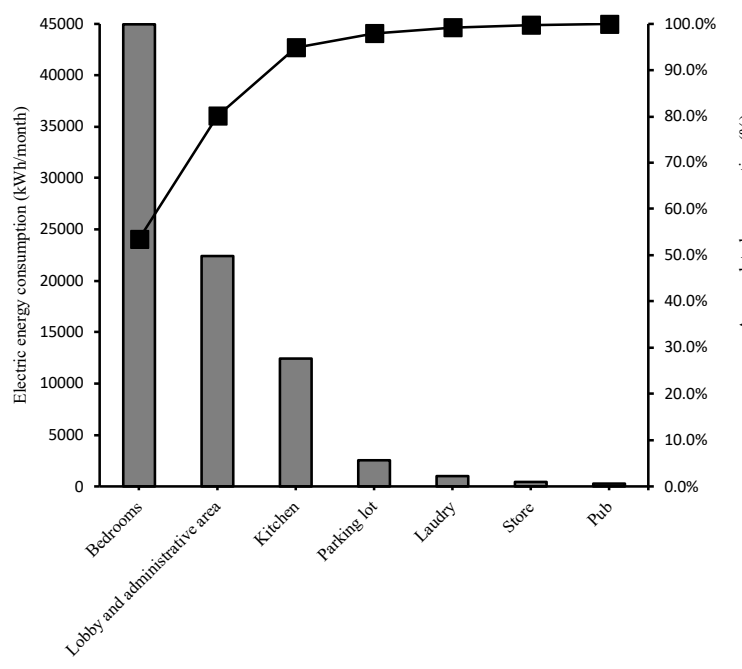

Fig. 5. Electricity consumption by area.

The following is concluded from the energy diagnosis:

1. The areas with the greatest electrical consumption are the rooms, lobby and administrative area with more than $80 \%$ of the energy consumption. The air conditioning system in the administrative and lobby area is available 24 hours a day regardless of the thermal load at a set point temperature of $16^{\circ} \mathrm{C}$.

2. There is a poor management of the rooms in relation to energy consumption. The personnel in charge of allocating the rooms to guests do so randomly, thus causing the use of different air conditioning systems in the corridors without there being any the need in productive terms.

Figure 6 shows the consumption of electricity by technological systems.

The greatest electricity consumption comes from the air conditioning system, which coincides with the results shown in figure 5, since the areas with the highest energy consumption use it intensively, therefore the actions for reducing the energy consumption should concentrate on this system and the proper use of the equipment that composes it.

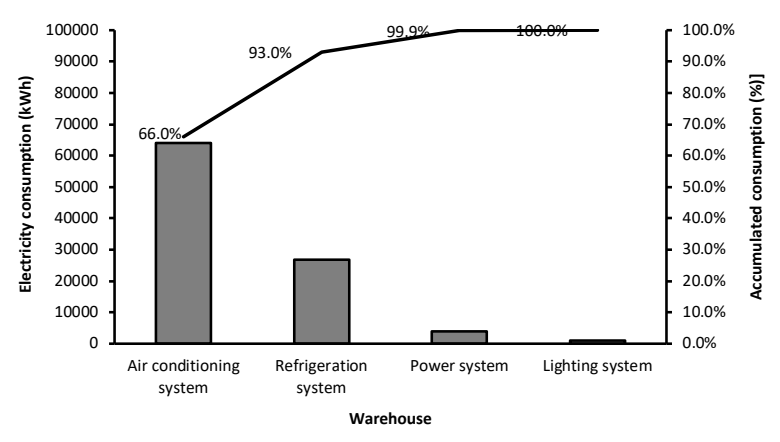

Fig. 6. Electrical consumption by technological system.

\subsection{Implemented savings measures}

Four savings measures were identified through an energy review of the air conditioning systems and three were immediately implemented:

1. The random room allocation system that caused the simultaneous use of climate control equipment in several floors not fully occupied, is replaced by the programmed assignment for floor-to-floor occupancy, staggering the startup of the air conditioning equipment.

2. Implementation of a protocol of operation for the air conditioning equipment, fixing the lag of the operating temperature without affecting the comfort of the guests. Currently, the temperature is set at 16 degrees Celsius without considering that for each degree below the temperature actually required an additional 7 and $8 \%$ of electricity is consumed [19]. For this, the thermal sensation for the conditions in Barranquilla was evaluated, where the relative humidity averages between $77 \%$ and $90 \%$.

To evaluate the thermal sensation, the adjusted Refrigeration Power equation was used [39, 40] which considers the relative humidity parameter, the variation of the ambient temperature and the height. The thermal sensation is classified in 7 levels.

Table 2. Thermal comfort index [40, 39].

\begin{tabular}{c|c}
\hline Comfort index & Thermal sensation \\
\hline 0 to 3 & Scorching \\
3.1 to 5 & Hot \\
5.1 to 7 & Warm \\
7.1 to 11 & Agreeable \\
11.1 to 13 & Cool \\
13.1 to 15 & Cold \\
Mayor to 15 & Freezing \\
\hline
\end{tabular}

The equation used for its calculation was:

$$
I C=(36.5-t)\left(0.05+\frac{h}{250}\right)
$$

For elevations less than 1000 meters.

Where $\boldsymbol{I C}$ is the comfort index, $\boldsymbol{h}$ is the relative humidity $(\%)$ and $\boldsymbol{t}$ is the local ambient temperature in Celsius.

Then the set point for a humidity of $83,5 \%$ and a 7,1 comfort index is: $t=18 \mathrm{C}^{\circ}$

From the results, it is concluded that the set point temperature can be increased in order to reduce the energy consumption. Therefore, it was suggested for the set point 
temperature of the air conditioning system in the Lobby and in the administrative area to be changed to $18^{\circ} \mathrm{C}$ for the hours between 11:30 am to $2: 30 \mathrm{pm}$, thus setting up a nice thermal sensation index. For the rest of the operating hours, a set point temperature between $22^{\circ} \mathrm{C}$ and $23^{\circ} \mathrm{C}$ was used experimentally, considering guest satisfaction surveys regarding the thermal sensation. The survey showed a result of $95 \%$ pleasant feeling.

In the rooms a standard set point temperature of $20^{\circ} \mathrm{C}$ was implemented, which must be set by the staff in charge, however the guests can modify it to their liking.

3. Reduction of the operating hours of the air conditioning system in the lobby, disconnecting it between 2:00 a.m. and 5:00 a.m., taking advantage of the decrease in the thermal load due to the lack of people and the smaller difference between the ambient temperature and the comfort at that time.

4. Incorporation into the service protocol in the rooms of the following actions that contribute to energy saving: 1 . Set the temperature selector of the refrigerator in economic mode if there is no guest, 2. Close the curtains of the windows whenever possible in order to decrease the thermal load produced by the radiation coming from the Sun; 3 . Increase the cleaning frequency of the air filters in the air conditioning systems in order to maintain the amount of refrigerated air and 4. Periodically cleaning the water pipes of the cooling system.

\section{Results and discussion}

Figure 8. Shows the base indicator 100 before and after implementing the energy saving measures. The base 100 efficiency indicator shows the energy performance by facilitating the analysis of the energy consumption for a period in relation to the initial baseline. This is used to know if the energy consumption was efficient or not in relation to the previous periods stipulated by the initial baseline.

$\%_{\text {Indicador }}$ base100 $=\frac{E_{\text {Lineabase }}}{E_{\text {real }}} X 100 \%$

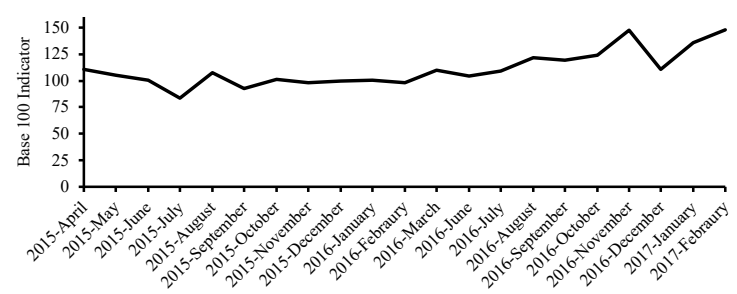

Fig. 8. Base 100 Indicator.

After applying the saving measures, the energy consumption improved in relation to the baseline in each month and energy efficiency was increased (see figure 8), because the base 100 indicator was greater than one hundred in all the months during which the saving measures were implemented.

Figure 9 shown the Graph of tendency or CUSUM accumulated amounts. The graphical indicator of trend or accumulated sums indicates the variation of energy consumption in relation to a given period, thus indicating the amount of current saved energy considering current production base [24].

Cusum $=\left(\left(E_{\text {real }}-E_{\text {Linea base }}\right)_{i}+\left(E_{\text {real }}-E_{\text {Linea base }}\right)_{i-1}\right)$
In Figure 9,shows that after the implementation of the saving measures, the energy consumption is in an area of conformity, that is, below 0 . The points indicate that the current energy consumption compared to the consumption of the baseline before implementing the savings measures, are lower in relation to the same occupation (HDO), therefore, the energy savings are greater. However, although the trend graph is satisfactory, care must be taken in periods where the slope tends to be parallel to the horizontal axis as in the case of the period between November and December.

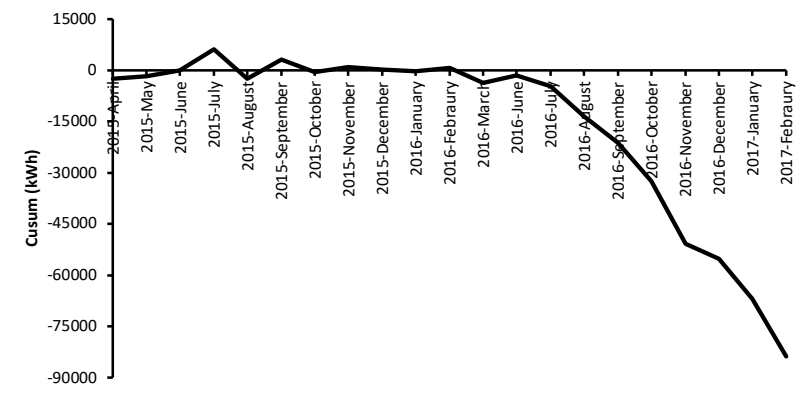

Fig. 9. Trend chart or accumulated sum of consumption in the months of implementation of the savings measures.

After implementing the saving measures it is possible to determine the energy savings by comparing the baseline with the actual consumption during the implementation period of the savings measures.

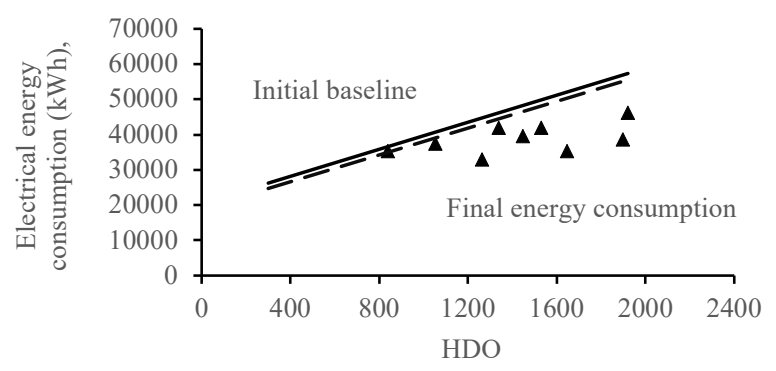

Fig. 10. Results of the implementation of the savings measures in the hotel.

Figure 10 shows that the trend of energy consumption during planning decreased and therefore its efficiency increased.

\footnotetext{
$\%$ Monthlyenergysavings

$=\frac{\text { Consumptionatbaseline }_{\text {Current } H O D}-\text { Realconsumption }_{\text {Current } H D O}}{\text { Consumptionatbaseline }_{\text {Current } H O D}}$ $* 100 \%$
}

The energy savings during the implementation period of the energy planning would be the sum of the monthly \% energy savings.

\section{$\%$ Total Energy Savings $=19.37 \%$}

The reduction of the hotel's energy consumption was $19.37 \%$ compared to the previous period. In Figure 10, it can be seen that the results in terms of energy efficiency were greater than the baseline and the target line, ratifying the effectiveness of the savings measures carried out. With this, it is shown that the savings measures were effective along with the development of good practices in the processes involved in the areas of greater electricity consumption. It was 
observed that in some of the months its effectiveness decreases, justified by management due to the high levels of occupation, festivities and procedures required by the hotel in those months.

\section{Conclusions}

The proposed methodology to implementing energy planning ISO 50001 procedure in Colombian tropical hotels was validated in a hotel in Barranquilla, the result shows a 19.37 $\%$ of energy savings throughout energy-saving measures implementation, mainly focused in bedrooms management and air conditioner systems improvement. Also, the poor level of energy management capacity was identified.

The energy performance and energy baseline applied shows its usefulness and evidenced that outdoor temperature and rooms occupied days are the main variables which influence in electricity consumption. The applied methodology is able for use in other hotels in the region.

This is an Open Access article distributed under the terms of the Creative Commons Attribution License

\section{References}

[1] P. Bohdanowicz, A. Churie-Kalhauge and I. Martimac, "EnergyEfficiency and Conservation in Hotels-Towards Sustainable Tourism," 4 W International Symposium on Asia Pacific Achitecture, Hawai, USA, (2001).

[2] United Natios World Tourism Organization, "'UNWTO tourism highlights 2014 edition". Available: http://mkt.unwto.org/es/publicaion/panorama-omt-del-turisointeracional-edicin-2014, (2014).

[3] B. A. D.Scott, B. S., C. J.P, D. G., G. S. and S. M., "Respoding to global challenges," in "Climate change and tourim", Switzerland, (2008).

[4] P. Xu, E. H.W.Chan, H. J.Visscher, X. Zhang and Z. Wu, "Sustainable building energy efficiency retrofit for hotel buildings using EPC mechanism analytic Network Process (ANP) approach", Journal of Cleaner Production, p. 378 (2015).

[5] J. J. Cabellos Eras, V. Sousa Santos, A. Sagastome Gutirrez, M. A. Guerra Palencia, D. Haeseldonckx and C. Vandecasteele, "Tools to improve forecasting and control of th electricity consumption in hotels," Journal of Cleaner Production, p. 803 (2016).

[6] J. Kelly and P. W. Williams, ". Modelling Tourism Destination Energy Consumption and GrEE nhouse Gas Emissions: Whistler, British Columbia, Canada.," Journal of Sustainable Tourism, p. 67 (2007).

[7] T. Mihalic, ". Sustainable-responsible tourism discourse - Towards 'responsustable' tourism," Journal of Cleaner Production, p. 461 (2016).

[8] W. Xuchao, R. Priyadarsini and L. Siew Eang, "Benchmarking energy use and greenhouse gas emissions in Singapore's hotel industry," Energy Policy, p. 4520 (2010).

[9] P. Bohdanowiscz and I. Martinac, "Determinants and benchmarking of resource consumption in hotels-Case study of Hilton International and Scandic in Europe," Energy and Buildings, p. 82 (2007).

[10] M. García Samper, J. García Guiliany and J. Cabello Eras, "EFICIENCIA EN EL USO DE LOS RECURSOS Y PRODUCCIÓN MÁS LIMPIA (RECP) PARA LA COMPETITIVIDAD DEL SECTOR HOTELERO," Revista de Gestão Social e Ambiental - RGSA, p. 18 (2017).

[11] Hotel Energy Solutions, " Analysis on Energy Use by European Hotels: Online Survey and Desk Research," Hotel Energy Solutions project publications, (2011).

[12] Govierno de Australia, "Energy Efficiency Opportunities in the Hotel Industrial Sector.," Department of Industry, Turism and resources, (2002).

[13] M. A. Köseoglu, E. S. Chan, F. Okumus and M. Altin, "How do hotels operationalize their competitive intelligence efforts into their management processes? Proposing a holistic model," International Journal of Hospitality Management, (2018).

[14] K. K.W. Wan, D. H.W. Li, D. Liu and J. C. Lam a, "Future trends of building heating and cooling loads and energy," Building and Environment, p. 223 (2016).

[15] M. Hui and M. Wong, "'Benchmarking the energy performance of hol buildigs.," (2010).

[16] A. Milojkovic, M. Nikolic and A. Stankovic, "'Improvement of energy efficiency in hospitality-towarards sustainable hotel"," IV Iternational Symposium for Students of Doctoral Studies in the Fields of Civil Engineerin, Architecturee and Enviromntal Protection, (2012).
[17] j. Chun Wang, "'A study on the energy performance of hotel building in Taiwan"," Energy Buildings, p. 268, (2010).

[18] J. Nuñez-Cacho del Aguila, "Gestión Energética en Hoteles,". [Online]. Available: https://www.fenercom.com, (2004)

[19] Agencia Provincial de la Energía de Alicante, "alicantenergia.es. Available: $\quad$ http://www.alicantenergia.es/images/2/-$31 \quad 104020$ 5050.pdf., (2017).

[20] Unidad de Planeación Minero Energética (UPME), "Proyección de Demanda de Energía en Colombia," (2010).

[21] Ministerio de Minas y Energía de Colombia, Available: http:/ www.minminas.gov.co/documents/10180/712360/Anexo+General+ del+RETIE+2013.pdf/14fa9857-1697-44ed-a6b2-f6dc570b7f43, (2013).

[22] Unidad de planacion Minero Energetica (UPME), "Guía para el consumo consciente, racional y eficiente de la energía. Industria hotelera, comercial e institucional. Zonas cálidas tropicales de Colombia. San Andrés, Providencia y Santa Catalina, Amazonas y Chocó Charlies Impresores Ltda.,".Available:http://www.si3ea.gov.co/LinkClick.aspx?fileticke $\underline{\mathrm{t}=\text { wru } 7 \mathrm{z} 0 \mathrm{gVd} \% 2 \mathrm{FI} \% 3 \mathrm{D} \& \text { tabid=123\&mid=449\&language }=\text { en-US }}$, (2014).

[23] ISO, "ISO 50001. Requirements with guidance for Use, " Energy Management Sytems, (2011).

[24] Guerrero, J. W. G., Toscano, A. D. R., Pacheco, L. V., \& Tovar, J. O. Analysis of the Energetic and Productive Effects Derived by the Installation of a Conveyor Belt in the Metal-mechanic Industry. International Journal of Energy Economics and Policy, 8(6), p.196 (2018).

[25] J. Madrigal, J. Cabello, H. Hernandez, M. Balbis and V. Sousa, "Planificación energética para el ahorro de fueloil en una lavandería industrial," Ingeniare, 6(1), p. 86 (2018).

[26] I. p. 1. D. y. A. d. 1. E. (IDAE), "Consumo eficiente y responsable de la Energía, Guía . Práctica.,". Available: http://www.ceisp.com/fileadmin/pdf/Guia_de la energia/IDAE $\mathrm{Gu}$ a de la Energ a 2007.pdf, (2017)

[27] S. Deng, "Energy and water uses and their performance explanatory indicators in hotels in Hong Kong," Energy Build, 35, p. 775, (2003).

[28] R. Castrillon, A. Gonzalez and E. Quispe, "Mejoramiento de la eficiencia energética en la industria del cemento por proceso humedo a traves de la implementación del sistema de gestión integral de la energía," Dyna, 80, p. 177 (2013).

[29] J. Yanes and O. Gaitan, "Herramientas para la gestion energetica empresarial," Scientia et technica, 3, p. 29 (2005).

[30] A. Sgastume, J. Cabello, V. Sousa, H. Hernandez, L. Hens and C. Vandecasteele, "Electricity management in the production of leadacid batteries: The industrial case of a production plant in Colombia," Journal of Cleaner Production, 198, p. 1143, (2018).

[31] J. Madrigal, J. Cabello, A. Sagastume and M. Balbis, "Evaluation of Air Conditioning in Commercial Buildings, Integrating Thermography Techniques, Simulation and Modeling by Finite Elements," Información tecnológica, 29(4), p. 179 (2018).

[32] D. Gordic, M. Babic, N. Jovic ic, V. Šušteršic, D. Konc alovic and D. Jelic, "Development of energy management system - Case study of Serbian," Energy Conversion and Management, 51, p. 2783 (2010). 
Andres Rodriguez, Toscano, Juan J. Cabello Eras, Fabrizio Galeano Viviente, Alexis Sagastume Gutierrez and Yabiel Pérez, Gomez/ Journal of Engineering Science and Technology Review 12 (5) (2019) 91 - 97

[33] M. B. ,. N. J. ,. V. Š. D. K. ,. D. J. Dušan Gordic' *, "Development of energy management system - Case study of Serbian," Energy Conversion and Management, 51, p. 2783, (2010).

[34] Wunderground. Available: https://www.wunderground.com/, (2017)

[35] S.-M. Deng and J. Burnett, "A Study of energy performance of hotel building in Hong Kong," Energy and Buildings, p. 7 (2000).

[36] R. Priyadarsini, W. Xuchao and L. S. Eang, "A Study on energy performance of hotel buildings in Singapore," Energy and Buildings, p. 1319 (2009).

[37] M. Karagiorgas, T. Tsoutsos and A. Moiá-Pol, "A simulation of the energy consumption monitoring in Mediterranean hotels: Application in Greece," Energy and Buildings, p. 416 (2007).
[38] D. S. C., M. Hui, M. M. C and W. Wan , "Study of hotel energy performance using data envelopment analysis.," paper presented at 12th International Conference on Sustainable Energy technologies, (2013).

[39] IDEAM, "Clasificaciones climáticas y confort térmico anual.," in Atlas Climatológico de Colombia, 2, p. 78 (2005).

[40] IDEAM, "CAMBIO CLIMÁTICO EN TEMPERATURA, PRECIPITACION Y HUMEDAD RELATIVA PARA COLOMBIA USANDO MODELOS METEOROLÓGICOS DE ALTA RESOLUCION (PANORAMA 2011-2100)," Bogota, (2010). 